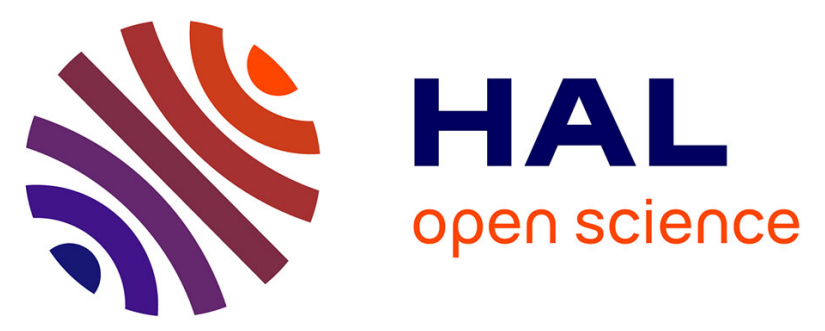

\title{
Heavy metals backgrounds and guiding values in southwestern amazonian soils - A comparative study
}

Fernando Machado de Mello, Maria Eduarda L.R. Teodoro, Gustavo N.C. Mesquita, Helena Saraiva Koenow Pinheiro, Essaid Bilal

\section{- To cite this version:}

Fernando Machado de Mello, Maria Eduarda L.R. Teodoro, Gustavo N.C. Mesquita, Helena Saraiva Koenow Pinheiro, Essaid Bilal. Heavy metals backgrounds and guiding values in southwestern amazonian soils - A comparative study. Carpathian Journal of Earth and Environmental Sciences, 2020, 15 (1), pp.71 à 86 . 10.26471/cjees/2020/015/110 . emse-02905142

HAL Id: emse-02905142

https://hal-emse.ccsd.cnrs.fr/emse-02905142

Submitted on 31 Aug 2020

HAL is a multi-disciplinary open access archive for the deposit and dissemination of scientific research documents, whether they are published or not. The documents may come from teaching and research institutions in France or abroad, or from public or private research centers.
L'archive ouverte pluridisciplinaire HAL, est destinée au dépôt et à la diffusion de documents scientifiques de niveau recherche, publiés ou non, émanant des établissements d'enseignement et de recherche français ou étrangers, des laboratoires publics ou privés. 


\title{
HEAVY METALS BACKGROUNDS AND GUIDING VALUES IN SOUTHWESTERN AMAZONIAN SOILS - A COMPARATIVE STUDY
}

\author{
Fernando Machado de MELLO ${ }^{1}$, Maria Eduarda Loureiro dos Reis \\ TEODORO $^{2}$, Gustavo Neves Costa de MESQUITA ${ }^{3}$, Helena Saraiva Koenow \\ PINHEIRO $^{4}$ \& Essaid BILAL ${ }^{*}$
}

${ }^{1}$ Universidade Federal Rural do Rio de Janeiro (UFRRJ). Rod. BR 465, km 7, CEP 23890-000 - Seropédica-RJ, Brazil; Tel.+55-2137873673 E-mail:fermamll@ufrrj.br;

${ }^{2}$ Universidade Federal Rural do Rio de Janeiro (UFRRJ). Rod. BR 465, km 7, CEP 23890-000 - Seropédica-RJ, Brazil; Tel. + 55- 2137873673 E-mail: me.loureiro@gmail.com.;

${ }^{3}$ Universidade Federal Rural do Rio de Janeiro (UFRRJ). Rod. BR 465, km 7, CEP 23890-000 - Seropédica-RJ, Brazil; Tel. + 55- 2137873673 E-mail: gustavonevescm@gmail.com;

${ }^{4}$ Universidade Federal Rural do Rio de Janeiro (UFRRJ). Rod. BR 465, km 7, CEP 23890-000 - Seropédica-RJ, Brazil; Tel. + 55- 2137873772 E-mail: lenask@gmail.com;

${ }^{5}$ Ecole des Mines de Saint Etienne (EMSE), Centre SPIN, CNRS UMR 5600, F42023 Cours Fauriel, 158. Saint-Étienne, France cedex 2. Tel. : +33(0)4 77420163 *E-mail corresponding author: ebilal@emse.fr

\begin{abstract}
Quality assessment of soils requires knowledge of distinct pollutant sources and process that leads the enrichment of harmful substances, by natural or anthropogenic causes. Reference values to chemical substances contents are used to characterize polluted or contaminated areas based preliminarily on background values. A background value refers to the natural concentration of an element or a substance in soils that have not been modified by anthropogenic activities aspects impacts. The establishment and distinction of these contents from different sources, regarding their strict reference values, guides normative instructions and some environmental laws in several countries, establishing the classification of areas with distinct levels of contamination. Decreasing soil quality by means of contamination and pollution by heavy metals is nowadays recognized as a serious risk for environmental quality and to the human health. Thus, the study goal consists in a reflection about the mineral nature of soils (reference values) and anthropic input in areas under pressure from agricultural frontiers, using as a case study the Southwest region of Amazonia. The study also proposes a comparison with the current situation in Europe, in order to subsidize the elaboration of public policies for the region under pressure of agricultural use in Brazil. In southwestern region of Brazilian Legal Amazon region, the land use is facing a continuous transformation, from mining activities and wood extraction to agricultural practices with intense use of fertilizers. These practices contribute with great volumes of heavy metals added to a weak tropical soil in this frontier region, characterized by land use conflicts between areas of indigenous reserves, farmlands and illegal mining activities. This work deals with the state of the art of legislation and proposals for reference values of some harmful substances suitable to the region and a preliminary delineation of conditions and vectors that allows their expansion. In this protective sense, intergovernmental actions aiming the control of pollution by heavy metals, particularly Cadmium, among other chemical components, pointing to a more restricted use of phosphate fertilizers, rich in heavy metals, are recommended in several countries of the European community. European reference values are compared to the values practiced in Mato Grosso e Rondônia States, Brazil, as well as an analysis of several procedures to obtaining the reference values.
\end{abstract}

Keywords: Tropical Soil; Heavy Metals; Fertilizers; Reference Values; SW-Legal Amazônia.

\section{INTRODUCTION}

The soil contamination is a threat to public health in many countries, and for this reason studies regarding the source of this contamination, that can be natural values intrinsic to the parental material or 
anthropic inputs due the soil management, is one of the first step to understand and to reduce the contamination from anomalous heavy metals concentration in soils.

The soil contamination by some heavy metals is a major environmental problem for two main reasons. Beside the risk in food, this contamination have very long-term effects due to its continuous concentration and have strong chemical and physical affinity for the solid matrix of distinct geologic grounds, besides a long residence time in soils (Echevarria \& Morel, 2006).

Inspired on this issue, increasing extensive biomedical research has shown strong correlation caused by cadmium in human diseases, as described in many documents in USA, comprising Soil Guideline Values (Environment Agency, 2009a), the framework documents updated technical background to the CLEA model (Environment Agency, 2009b), Human Health Toxicological Assessment of Contaminants in Soil (Environment Agency 2009c), and Contaminants in soil: Updated Collection of Toxicological Data and Intake Values for Humans (Environment Agency, 2009d).

According to the Brazilian environmental law (CONAMA Resolution No 420/2009), each Brazilian state (federation) must determine the reference values to improve quality control and risk assessment associated to the soil contamination and requires the knowledge of the total content and the influence of source rock in heavy metal elements (HME) in the various constituent compartments of the soils. In this sense, the present work considers the HME, based in its geochemical behavior as proposed by Alloway (2010), which considers the metals/metalloids as Siderophiles (Co, Ni, $\mathrm{Au}, \mathrm{Mo}, \mathrm{Pb}, \mathrm{As})$, Calchophiles $(\mathrm{Cu}, \mathrm{Ag}, \mathrm{Au}, \mathrm{Zn}, \mathrm{Cd}, \mathrm{Hg}, \mathrm{Pb}, \mathrm{As}, \mathrm{Sb}, \mathrm{Se}, \mathrm{Tl}, \mathrm{Mo}$ ) and the Lithophiles ( $\mathrm{V}, \mathrm{Cr}, \mathrm{Mn}, \mathrm{U}, \mathrm{Ti})$, and is focused on the $\mathrm{Cd}$ content on soil and rocks as an indicator of the fertilizers sources and lack of public policies in a Brazilian region under agriculture pressure.

Addressing this issue, concentrations of some Heavy Metals Elements (HME) in rocks and soils of Southwestern Legal Amazônia (herein referred as SWAM) are examined here, in a region of Brazil where the severe deforestation is linked to cattle pasture frontier expansion, a process that includes forest conversion for cropland, especially soybean, and conflicts with traditional preserved indigenous reservation areas partially occupied by illegal mining ("garimpo") and intense wood extraction/burning. Thus, the study goal consists in a reflection about the mineral nature of soils (reference values) and anthropic input in areas under pressure from agricultural frontiers, using as a case study the southwest region of Amazonia.

This work deals with aspects on HME contents in soils, specially cadmium (Cd), particularly in Mato Grosso (MT) and Rondônia (RO) states of Brazil. The aspects evaluated comprise the reference values, and preliminary evaluation of the additional input, mainly due to the application of huge volume of mineral fertilizers, since it is directly linked with their harmful concentrations. The current work has also the purpose to analyze and compare types of approaching to face this major issue in that region and in some developed countries regarding their HME reference values and the behavior of soil heavy metals, to compare methods of detection and regulations around the world and also compare the minimum concentrations to establish harmful levels and risk assessment.

\section{HEAVY METALS IN ROCKS, SOILS AND FERTILIZERS}

The phosphate rocks mined in Brazil, Finland, Russia, and South Africa are mainly igneous rocks and have very low cadmium contents (sometimes below $10 \mathrm{mg} \mathrm{kg}^{-1} \mathrm{P}_{2} \mathrm{O}_{5}$ ), but are richer in $\mathrm{U}$ and $\mathrm{Th}$, especially on Brazilian deposits. In the other hand, those found in North America (Florida, USA), North and West Africa and in the Middle East are sedimentary rocks formed in environments rich in organic matter and generally have higher Cd levels. In Florida (first national supplier in USA), Tunisia, Togo, Senegal, Morocco deposits, the most important suppliers of Brazil and European Union, the deposits present the same cadmium average contents in fertilizers (above $60 \mathrm{mg} \mathrm{kg}^{-1} \mathrm{P}_{2} \mathrm{O}_{5}$ ). Most natural soils contain less than $1 \mathrm{mg} \mathrm{Kg}^{-1}$ of residual cadmium from the weathering of parent materials (Alloway, 2010). Generally, lower levels from $\mathrm{Cd}$ are common in acid igneous rocks (granite average $0.09 \mathrm{mg} \mathrm{kg}^{-1}$ ) than basic (basalt average $0.13 \mathrm{mg} \mathrm{kg}^{-1}$ ). Sandstones and limestones show lower levels when compared to the higher contents found in black shales $(0.3$ to $219 \mathrm{mg}$ $\mathrm{kg}^{-1}$ ), organic-rich sediments or marine manganese nodules and phosphorite (Ferguson, 1990).

Only $10 \%$ of the $\mathrm{P}$ applied as a fertilizer is taken by the plants, differing in this aspect by the higher taken of $\mathrm{N}$ and $\mathrm{K}$ elements. This difference is attributed by the higher $\mathrm{P}$ fixation common in tropical soils with high contents of $\mathrm{Fe}-\mathrm{Al}$ oxides (Raij, 2003). The Brazilian consumption of $\mathrm{P}_{2} \mathrm{O}_{5}$ was in 2002 about 2.777.000t (Lopes, 2003), being 43\% from monoammonium phosphate (MAP), 30\% in the form of simple superphosphate (SSP), $15 \%$ triple superphosphate (TSP), and $12 \%$ of other sources.

Langenbach \& Sarpa (1985) compared the $\mathrm{Cd}$ concentration in eleven Brazilian phosphates and 
observed that their Cd contents are lesser than $2.0 \mathrm{mg}$ $\mathrm{kg}^{-1} \mathrm{Cd}$. The Brazilian phosphate rock from CatalãoGO shows $4 \mathrm{mg} \mathrm{kg}^{-1} \mathrm{Cd}, 19 \mathrm{mg} \mathrm{kg}^{-1} \mathrm{Cr}$ and $58 \mathrm{mg} \mathrm{kg}$ ${ }^{1} \mathrm{~Pb}$, and the fine apatitic concentrate from AraxáMG, $7 \mathrm{mg} \mathrm{kg}^{-1} \mathrm{Cd}, 44 \mathrm{mg} \mathrm{kg}^{-1} \mathrm{Cr}$ and $127 \mathrm{mg} \mathrm{kg}^{-1} \mathrm{~Pb}$ (Gabe \& Rodella, 1999). Amaral Sobrinho et al. (1992) presented typical ranges of HME in phosphate fertilizers as: $0.1-170 \mathrm{mg} \mathrm{kg}^{-1} \mathrm{Cd}, 7-225 \mathrm{mg} \mathrm{kg}^{-1} \mathrm{~Pb}$, $7-38 \mathrm{mg} \mathrm{kg}^{-1} \mathrm{Ni}, 1-300 \mathrm{mg} \mathrm{kg}^{-1} \mathrm{Cu}$ and $50-450 \mathrm{mg}$ $\mathrm{kg}^{-1} \mathrm{Zn}$.

The average $\mathrm{Cd}$ content in soil surface is estimated to be $0.53 \mathrm{mg} \mathrm{kg}^{-1}$, with all higher values reflecting anthropogenic influences (Kabata Pendias \& Pendias, 2001). Regarding the Brazilian soils, uneven distributed by different regions of the country, the dominant soil type is the Ferralsols (Latossolos), with $56.30 \%$ in total area, followed by the Acrisols (Argissolos) (20.68\%), both highly appreciated to agriculture (Coelho et al. 2002). That distribution is mostly due to the geologic ground and by extreme climatic differences in the country, and provides the development of agricultural soils, most of them with desirable physical properties (well-structured, high porosity) but with low fertility (problems with $\mathrm{P}$ fixation and acidity), which is modified through intense use of mineral fertilizers and other agricultural inputs.

A minor area, $16 \%$ percent of the Legal Amazon, has soils capable of fixing large quantities of phosphorus into relatively insoluble forms. Although most SWAM soils will require fertilizers to grown annual cultures, the quantities required are not likely to be as high as in the acid soils from Savannas (Cerrados), where high phosphorus fixation is a major problem (Sanchez et al., 1982). Soil and water contamination by HME in SWAM is largely due to agricultural practices and illegal mining.

The proposed HME baseline values of natural concentrations in Brazilian soils by Amaral Sobrinho (1993) suggests that different values of HME could be found in the same soil order, or between different soil types, as a function of the variation of soil characteristics. The research performed by Fadigas et al., (2006) assessing natural contents of HME in some soil types of Brazil divides the soils orders in seven groups (Table 1). Average values of the upper superior quartile (Table 1 - $\mathrm{QSm}^{2}$ values) are close to the quality reference values for São Paulo State (Brazil), in which the concentrations, in $\mathrm{mg} \mathrm{kg}^{-1}$ are: $\mathrm{Cd}$ (0.5), Co (12.5), Cu (35.1), Cr (40.2), Ni (13.2), $\mathrm{Pb}$ (17), Zn (59.9), according Casarini (2000).

Table 1. Normal considered values of $\mathrm{Cd}, \mathrm{Co}, \mathrm{Cr}, \mathrm{Cu}, \mathrm{Ni}, \mathrm{Pb}$ and $\mathrm{Zn}$ in natural soils, proposed as a reference Value (RV) ${ }^{1}$. (Modified from Fadigas et al., 2006)

\begin{tabular}{|c|c|c|c|c|c|c|c|}
\hline \multicolumn{8}{|c|}{ ELEMENT } \\
\hline \multirow{2}{*}{ GROUP (G) } & $\mathrm{Cr}$ & Co & $\mathrm{Ni}$ & $\mathrm{Cu}$ & $\mathrm{Zn}$ & $\mathrm{Cd}$ & $\mathrm{Pb}$ \\
\hline & \multicolumn{7}{|c|}{ Soil Concentration $\left(\mathrm{mg} \mathrm{kg}^{-1}\right)$} \\
\hline 1 & 55 & 20 & 35 & 119 & 79 & 1,0 & 19 \\
\hline 2 & 48 & 10 & 18 & 19 & 44 & 0,8 & 28 \\
\hline 3 & 65 & 4 & 25 & 16 & 23 & 1,6 & 16 \\
\hline 4 & 35 & 10 & 17 & 12 & 35 & 0,9 & 18 \\
\hline 5 & 23 & 4 & 7 & 6 & 12 & 0,4 & 22 \\
\hline 6 & 43 & 2 & 12 & 2 & 12 & 0,4 & 3 \\
\hline 7 & 19 & 2 & 5 & 3 & 6 & 0,3 & 40 \\
\hline $\mathrm{QSm}^{2}$ & 41 & 8 & 17 & 25 & 30 & 0,8 & 20 \\
\hline \multicolumn{8}{|c|}{$\begin{array}{l}{ }^{1} \text { Concentration considered normal for the soils belonging to each group and corresponding to the value of the upper } \\
\text { quartile }(75 \%) \text { of the frequency distribution of the sample data in each group. } \\
{ }^{2} \text { Mean upper quartile between groups }\end{array}$} \\
\hline
\end{tabular}

In Table 1, the first group of soils (1) is distinguished by high contents in $\mathrm{Mn}, \mathrm{Fe}$ and clay minerals, composed by Haplic Ferralsols, Dystric and Haplic Acrisols (Chromic) mainly formed in terrains with basaltic compositions, most of them over the border of the huge Paraná Sedimentary Basin. This is the group that naturally concentrates the highest values of HME. The second group (2) includes those with high levels of silt, Mn and high CEC (Cation Exchange
Capacity), including Chernozems, Luvisols, and other eutrophic soils, and few Ferralsols and Lixisols. The sixth and seventh groups (6 and 7) show the lowest levels in HME and share the same composition but are differentiated by clay and $\mathrm{Fe}$ contents, including Haplic Ferralsols (Xanthic) and Acrisols, and in minor quantity soils derived by Tertiary and Quaternary sediments. Third, fourth and fifth (3, 4 and 5) groups share intermediate characteristics of those cited above 
and are mainly constituted by a great variety of Ferralsols and Acrisols, and, with minor importance, by Plinthosols, Cambisols and Alisols.

\section{ANALYTICAL METHODS OF HEAVY METALS EXTRACTION COMPARED}

Most of international environmental agencies uses proposed methods by the United States Environmental Protection Agency (USEPA 3050 and 3051). In Brazil, they are the recommendation of National Environmental Council (CONAMA, 2009), through resolution 420/2009 Annex I, which establishes Quality Reference Values of inorganic substances, and recommendations overlook the differences between classes of organic soils. Similarly, The Acqua Regia (AR) method is also common around the world and has been used by the International Organization for Standardization (ISO $19258,2005)$ as the standard for soil certification in Europe. Recent brazilian studies indicate significant differences in the results and after using each method this situation requires choosing only one standard digestion method for purposes of comparison (Amaral Sobrinho, 1993; Saldanha et al.,1997; Melo \& Silva, 2008; Caires, 2009; Pérez et al., 2013; Santos \& Alleoni, 2013).

Significant differences were found in heavy metal extraction capacity between the AR and USEPA 3051 methods, wherein AR showed a better recovery rate for most metals analyzed upon testing different soils from the southwestern Amazon region (Santos \& Alleoni, 2013). Pérez et al. (2013) also showed that the AR method performed better than USEPA 3051 and 3051. Comparison of three extraction procedures was carried out by Campos et al. (2005) to assess HME in mineral fertilizers (Embrapa, 1997; USEPA 3051A and USEPA 3050B) for $\mathrm{Cd}, \mathrm{Cr}, \mathrm{Cu}, \mathrm{Ni}, \mathrm{Pb}$, and $\mathrm{Zn}$ from the main fertilizers commercialized in Brazil. The methods described do not fully solubilize the solid fraction of phosphates, been recommended instead total extractions for soil pollution studies, due to representation of maximum potentially bioavailable of a certain pollutant.

The tested methods applied in studies concerning heavy metals in samples of Brazilian natural phosphate fertilizers showed an average of $8.7 \mathrm{mg} \mathrm{kg}^{-1}$ of $\mathrm{Cd}$ content, whereas non-Brazilian ones presented higher values in average $77 \mathrm{mg} \mathrm{kg}^{-1} \mathrm{Cd}$, reactive phosphate from Morocco presented the greatest concentration of Cd (145 $\left.\pm 13 \mathrm{mg} \mathrm{kg}^{-1}\right)$ (Campos et al., 2005). Phosphate rocks (P sources) presented contents between $5 \pm 0,6$ and $145 \pm 13 \mathrm{mg} \mathrm{kg}^{-1}$. Those values are in the range observed by Kabata Pendias \& Pendias (2001) for phosphate fertilizers, varying between $0.1-170 \mathrm{mg} \mathrm{kg}^{-1}$ to $\mathrm{Cd}$ content. Bizarro et al. (2008) studied Cd contents in main phosphate fertilizers commercialized in Brazil, compared by Nitropercloric and USEPA 3050B methods and showed that differences occur, and the higher contents were found in natural $\left(42.6 \mathrm{mg} \mathrm{kg}^{-1}\right)$ and mono-aminated (31.0 $\left.\mathrm{mg} \mathrm{kg}^{-1}\right)$ phosphates from Morocco.

Experiments on simulation of inputs of HME shows that Cd increases with the application of 200 $\mathrm{kg} \mathrm{ha}^{-1}$ of the reactive phosphate from Morocco incorporated in $0.1 \mathrm{~m}$ depth of soil would reach 0.094 $\mathrm{mg} \mathrm{kg}{ }^{-1}$, and in that way needs 111 applications to attain the intervention level of $10 \mathrm{mg} \mathrm{kg}-1 \mathrm{Cd}$ (CETESB 2016). In the other hand, they noticed that in five years, $\mathrm{Cd}$ contents could double, from one average soil of $0.5 \mathrm{mg} \mathrm{kg}^{-1} \mathrm{Cd}$ (Campos et al., 2005).

In other hand for $\mathrm{Cu}$ content, there was no difference between the extraction methods. For Ni and $\mathrm{Zn}$ contents, there was no statistical difference between USEPA 3051A and USEPA 3050B, but the contents were superior than those determined by Embrapa (1997) method. The USEPA 3050B extracted more $\mathrm{Cd}$ than other methods, while for $\mathrm{Cr}$ contents, Embrapa method had higher extraction. The AR method proved to be suitable for heavy metal extraction from organic soils and can therefore be used as a standard method to determine quality reference values

Santos \& Alleoni (2013) chose representative brazilian municipalities for soil sampling, and were: Água Boa, Barão de Melgaço, Cáceres, Conquista d'Oeste, Itaúba, Itiquira, Nova Monte Verde, Novo São Joaquim, Pontes e Lacerda, Porto Esperidião, Ribeirão Cascalheira, São José do Xingu, Sorriso, and Sapezal in the state of Mato Grosso. In the state of Rondônia chosen counties were Ariquemes, Pimenteiras do Oeste, Rio Crespo, Santa Luzia do Oeste, and Theobroma. The authors found no difference in the levels of $\mathrm{Cr}$ and $\mathrm{Cu}$ extracted by those methods ( $\mathrm{p}<0.01$, in Santos \& Alleoni, 2013). For $\mathrm{Ni}, \mathrm{Pb}$, and $\mathrm{Zn}$, however, the percentiles established by Acqua Regia method were two to three times higher than those suggested by the USEPA 3051 method, which is the official recommendation method for determining QRVs for Brazilian soils.

A number of other $\mathrm{HME}$ such as $\mathrm{Zn}, \mathrm{Cu}, \mathrm{Hg}$, and Mn could have harmful human and environmental impacts at certain levels. $\mathrm{Cd}$ is the most toxic, and contaminated sites may remain as such for very long time. Its main source nowadays in SWAM are phosphate fertilizers in addition a natural contaminant in phosphate deposits, so may be transferred in fertilizers and taken up by vegetable roots (Jarup \& Akesson 2009). Unlike organic chemicals, HME do not degrade and may accumulate in the environment 
and become increasingly bio-available over time. Related impacts are often most severe in the developing countries and regions like SWAM where they are mined, processed, used and recycled with limited environmental control and regulation.

The determination of Quality Reference Values (QRVs) for heavy metals in soils is well established in several countries (Chen et al. 1991, 1993, 1997, 1999; Holmgren et al. 1993; Bak et al. 1997; Abollino et al., 2002; Horckmans et al., 2005; Fadigas et al., 2006; Mcgrath \& Zhao 2006; Salonen \& Korkka-Niemi 2007; Martinez-Lladó et al. 2008; Su \& Yang 2008; Brus et al., 2009). Few such values have been determined for Brazil, however. Over the last three decades, Brazilian researchers have worked to quantify and compare levels of naturally occurring metals in the country's soils (Amaral Sobrinho et al. 1992, Amaral Sobrinho 1993; Caires, 2009; Fadigas et., 2006; Campos et al. 2003; Lima et al., 2016; Mello et al., 2018).

The Brazilian Environmental Council (CONAMA, 2009), through Resolution n.420/ 2009, established that each state in the country must determine its own guiding values for heavy metal concentrations based on a set of soil samples that represent the local geomorphology, pedology and lithology. This was decided, among other reasons, because the international values, or those from other regions, might result in erroneous interpretation regarding areas suspected of being contaminated. The Brazilian resolution establishes three types of guiding values: Quality Reference Value (QRV, determined by each federation), Prevention Values (PV) and Investigation Values (IV), which are valid for the entire country. In São Paulo state the Intervention Values for agriculture destination were recently determined, mainly in topsoil, by CETESB (2016), are in expressed in $\mathrm{mg} \mathrm{kg}-1$ as follows: (As -35$),(\mathrm{Cd}$ -3.6), (total $\mathrm{Cr}$ - 150), ( $\mathrm{Cu}$ - 760), ( $\mathrm{Hg}$ - 1.2), (Ni $190),(\mathrm{Pb}-150)$ and $(\mathrm{Zn}-1,900)$.

\section{SOUTHWESTERN AMAZÔNIA (SWAM).}

LEGAL

Figure 1 highlights the Brazilian Amazon area, as well, the Rondônia and Mato Grosso States, as their respective land cover (imagens from ESRI Database 2018). These Brazilian states are highlighted once they comprise one of the last agricultural frontiers in the country, which faces great deforestation in these areas in recent years. These pressure areas, at the deforestation arch, resides also unprotected indigenous reserves that are one among other sinks after HME transportation along surficial drainage. Conflict Areas at the arch of deforestation of SWAM around Novo Progresso (MT) are depicted in Figure 2. In the SWAM fire is almost entirely from human activities and usually occurs in the driest period of the year. Deforestation and subsequent agricultural activities have increased in the last 40 years and fire is the main technique used to clear the land cover, renewing pasture areas. Although annual deforestation has sharply decreased from $27,772 \mathrm{~km} 2$ in 2004 to $4,571 \mathrm{~km} 2$ in 2012, it has been fluctuating since then, showing annual variation from $-15 \%$ up to $+29 \%$ (Fonseca et al. 2019).

While most Amazonian deforestation is due the conversion to cattle pasture, nowadays is also a shifting for soybean cropland in MT and RO, and this evidence suggests that despite the great area used pastures, the soy expansion may also drive deforestation at these last agricultural frontiers areas of the country. The conversion of native forests into pastures promoted reduction of organic carbon and microbial carbon stocks in the soil, mainly in cultivated pastures with longer implantation time.

Boundary shifted from cattle pasture to soya bean cropland in the last 20 years. During this time, amazon soybean production became a global industry placing Brazil as the world's second-largest soybean exporter. Much expansion of soya beans in the Amazon has occurred in the state of MT and has been concentrated in areas of low relief covered by highly weathered, acidic soils that are highly deficient in phosphorus. Recently, soya bean cultivation has intensified and double cropping of soya beans, mostly with corn, increasing the areas from $35 \%$ to $65 \%$ of MT croplands in a gap of ten years (Neill et al., 2013).

Several analyses of both the scope of potential environmental impacts and the opportunities for impact management in the Amazon soya bean region have been made by Neill et al., (2013). Investigations have been carried out on the agricultural dynamics related to soybean crop expansion toward the Amazon biome as a major driver of land-use and land-cover changes in Mato Grosso (Fearnside, 2001; Morton et al., 2006). Soybean crop area has expanded $275 \%$ over the last 20 years (IBGE, 2014). The total land-use shift into soybean in MT from 2001 to 2011 was almost 8.7 million ha, of which almost 3.5 million ha belonged to the Brazilian Amazon biome and most of these areas are currently being gradually abandoned (Gusso et al., 2017).

In the high Guaporé River Valley (RO), the frontier areas are suffering a rapid change with the continuous processes of farmland expansion northward, towards the largest tropical forest in the word, the Amazon Forest, and over protection areas. 

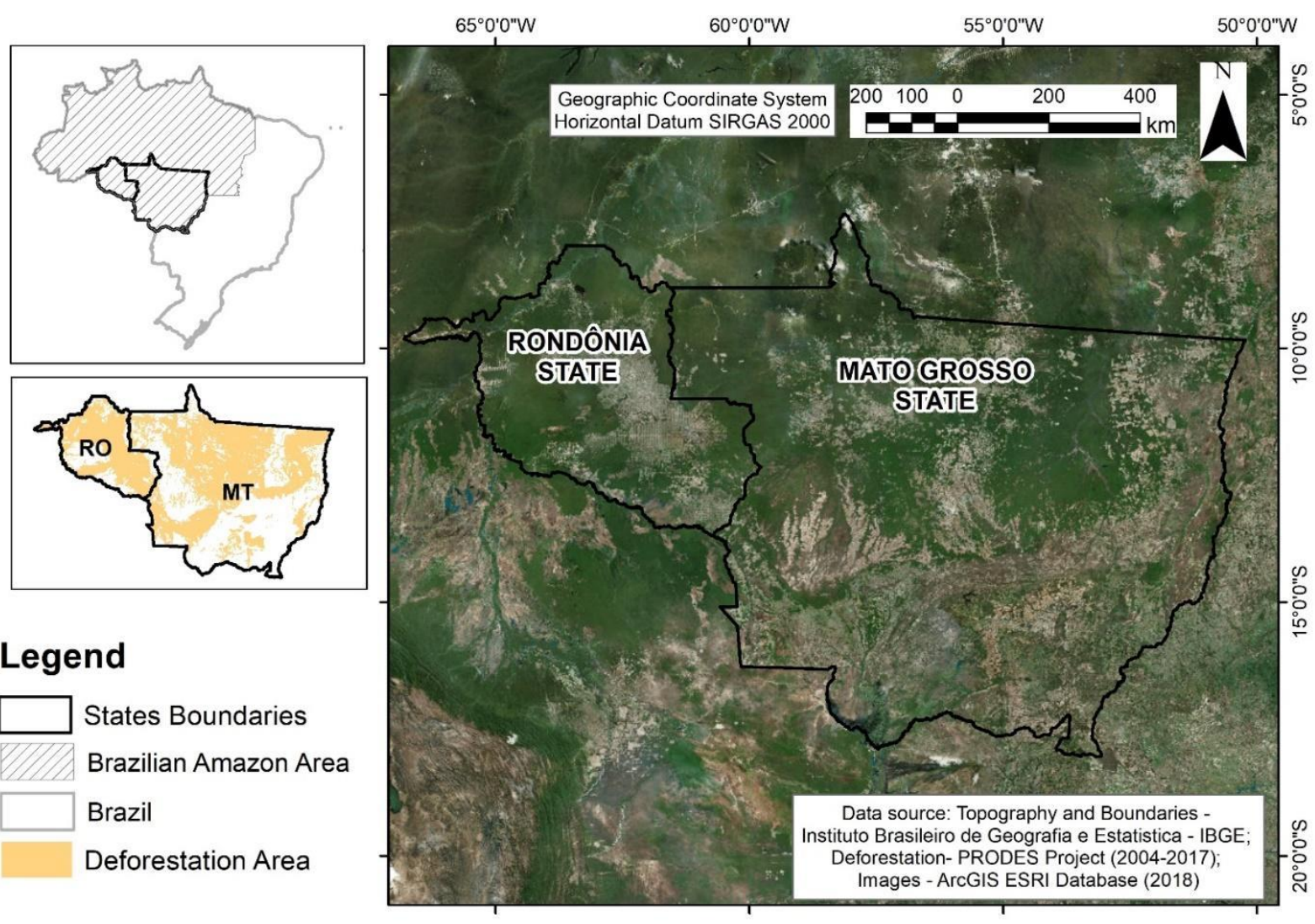

Figure 1. Location of Brazilian SW-Amazon Area, highlighting Rondônia and Mato Grosso States, deforestation areas and main Indigenous Reserves.

The deforestation advances by using, in a large scale, the traditional method of "Coivara", which burns the savannas and amazon forest, establishing extensive crop areas of soybean, cotton and corn, notably in Guajará-Mirim, Costa Marques, São Francisco do Guaporé, São Miguel do Guaporé, Pimenteiras do Oeste, Corumbiara, Cerejeiras e Cabixi. In the region of the N-S axe of the BR-163 national route, Sorriso and Lucas do Rio Verde were ranked as the area of highest soybean production in the state of MT, and this state became the largest producer of soybean in Brazil and accounted for approximately $28.9 \%$ of national production (CONAB, 2015).

It is also important to consider local conditions that could lead to losses by erosion, enhanced by fires, of soil particles enriched with heavy metals, transported to other areas or water bodies. Figure 3 depicts a terrain model of RO and MT, over the Height Above Nearest Drainage (HAND) background that is a drainage-normalized and flowpath-coherent version of a digital topographical map using a digital elevation model (DEM) as input and the drainage network (Nobre et al., 2011). HAND contours maintain a topological relationship with the water level of the nearest channel because the channel becomes the normalized reference height (uniform and set to zero) for the surrounding terrain in the model. The distribution of most elements in soil shows a pattern strong related to hydrologic aspects, geology and/or mineralization.

The conditions that determine the soil adsorption capacity, such as $\mathrm{pH}$, organic matter content, content of clay minerals and $\mathrm{Fe}-\mathrm{Al}$ oxides, affect the availability and mobility of heavy metals presents in phosphates (Abdel-Haleem et al., 2001). It is also important to consider local conditions that could lead to losses by erosion of soil particles enriched with heavy metals, transported to other areas or water bodies. Figure 3 depicts a terrain model of RO and MT, over the Height Above Nearest Drainage (HAND) background that is a drainage-normalized and flowpath-coherent version of a digital topographical map using a digital elevation model (DEM) as input and the drainage network (Nobre et al., 2011). HAND contours maintain a topological relationship with the water level of the nearest channel because the channel becomes the normalized reference height (uniform and set to zero) for the surrounding terrain in the model. The distribution of most elements in soil shows a pattern strong related to hydrologic aspects, geology and/or mineralization. 


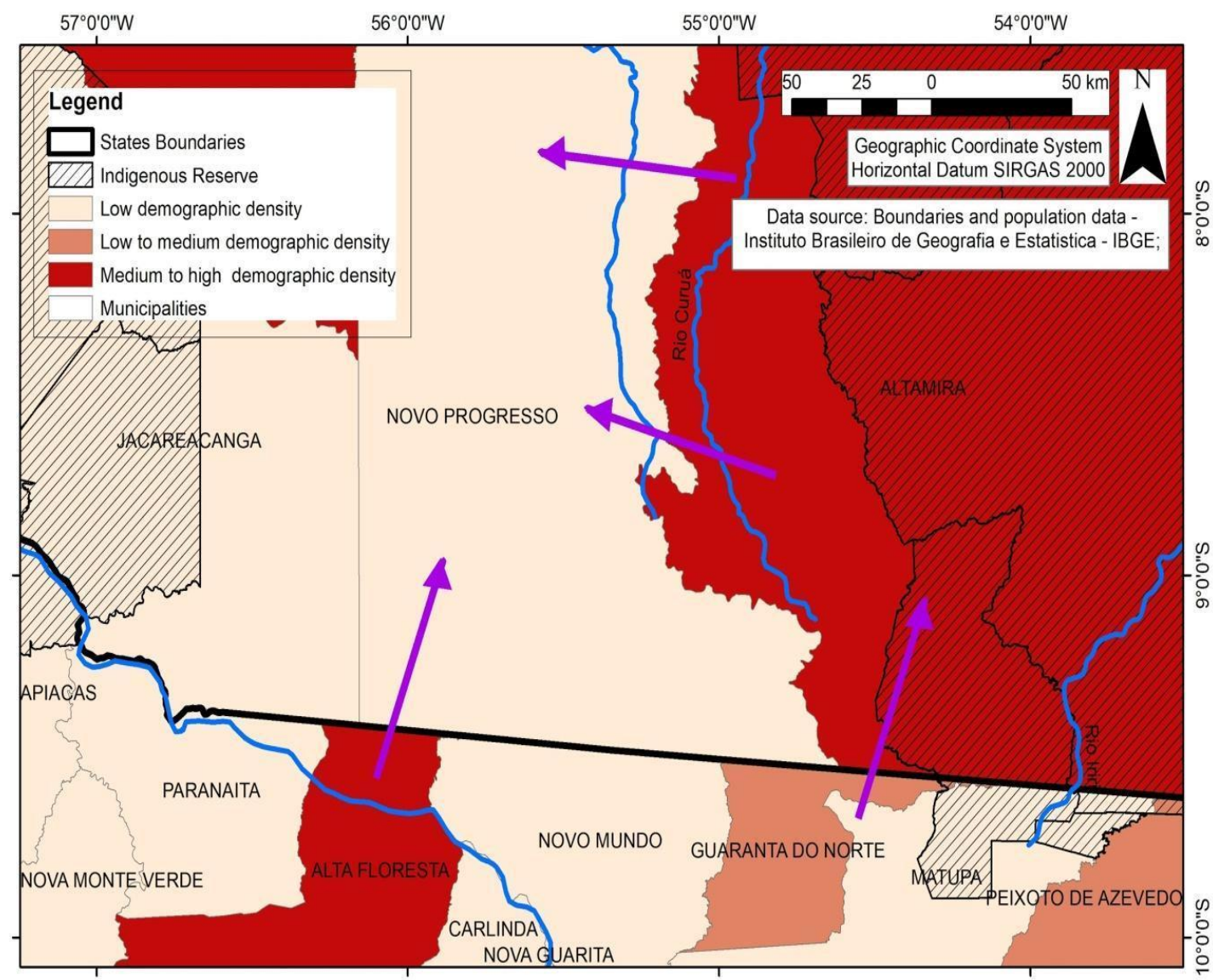

$\begin{array}{llrl}57^{\circ} 0^{\prime} \mathrm{O}^{\prime \prime} \mathrm{W} & 56^{\circ} 0^{\prime} \mathrm{O}^{\prime \prime} \mathrm{W} & 55^{\circ} 0^{\prime} \mathrm{O}^{\mathrm{N}} \mathrm{W} & 54^{\circ} \mathrm{O}^{\prime} \mathrm{O}^{\prime \prime} \mathrm{W}\end{array}$

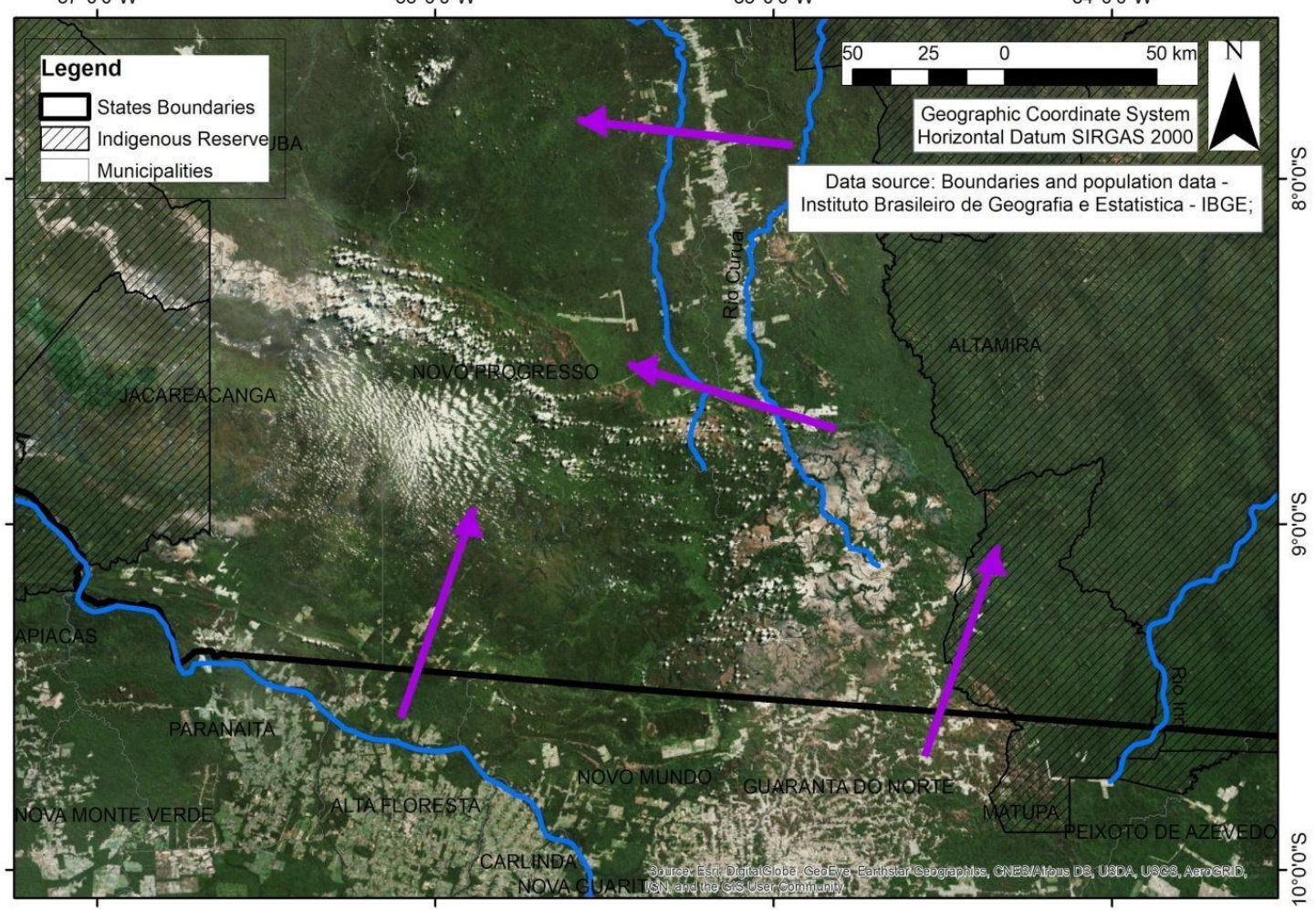

Figure 2. Conflict areas at the arch of deforestation of SWAM around Alta Floresta (MT), arrows are fronts of croplands expansion, the hatched areas are indigenous reserves, in the upper figure. Lower figure is the same area in a true color image from ESRI database 2018. 

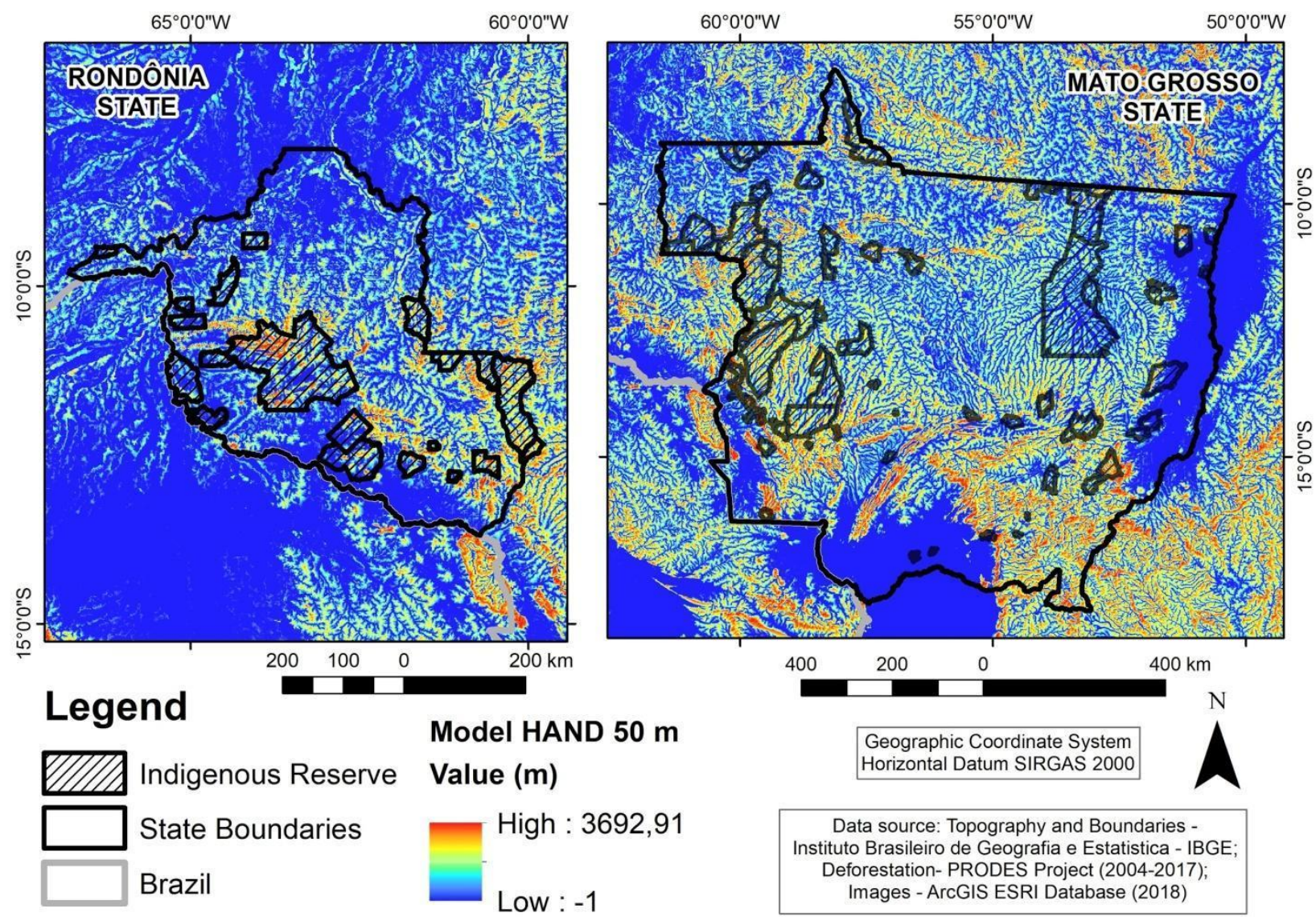

\section{.}


The conditions that determine the soil adsorption capacity, such as $\mathrm{pH}$, organic matter content, content of clay minerals and $\mathrm{Fe}-\mathrm{Al}$ oxides, affect the availability and mobility of heavy metals presents in phosphates (Abdel-Haleem et al., 2001).

The acidity of soils controls the distribution of HME in soils, the adsorption and desorption of $\mathrm{Cd}$ and $\mathrm{Zn}$ presents a great sensibility to $\mathrm{pH}$, compared with $\mathrm{Cu}$ and $\mathrm{Pb}$. This chemical behavior could contribute to explain the accumulation $\mathrm{Zn}$ and $\mathrm{Cd}$ in soil surficial layers in locals with higher $\mathrm{pH}$ (Alloway, 1995) and more organic carbon contents in topsoils (upper soil layer, usually the top $5 \mathrm{~cm}$ to 20 $\mathrm{cm}$ depth), particularly in tropical soils. The topsoil layer has the highest concentration of SOM (Soil Organic Matter) and microorganisms holding most of the biological activity on soils and plants generally concentrate their roots there to obtain nutrients. For this reason, topsoil layer is also more affected with agricultural inputs.

Geodiversity can be defined as the natural range (diversity) of geological (rocks, minerals, fossils), geomorphological (landforms, topography, physical processes), soil and hydrological features, including their assemblages, structures, systems and contributions to landscapes (Gray et al., 2013). In the Geodiversity Maps (CPRM, 2006) units were used to synthesize major geosystems present at SWAM, their respective environmental pressures, limitations and potentials, based on the lithological constitution analysis of the geological supra and infra-structure, and the relation to support human activities. Fragile geodiversity units suitable to HME contamination identified are Reworked Sediments of Other Rocks (DCSR), corresponding to a Geologic Unit of Undifferentiated Sedimentary Covers in MT (Detritic-Lateritic Cenozoic Covers -DCDL) and units in the Domain of Mesozoic and Paleozoic Volcano-Sedimentary and Sedimentary Covers moderately consolidated, associated with large and deep Syneclises-type Sedimentary Basins. These units were related to a major geomorphological region in SWAM (Fig. 4). The analysis of each geosystem characteristics (Table 2) supports the identification of fragile soils with naturally high HME contents and vectors of stressing forces inducing the environmental quality decay, specially areas for the soybean crops that are intensely fertilized.

Over the flats areas at the "Chapada" also known as "Planalto dos Parecis" in MT, soybean and corn crops are developed in Haplic Ferralsols (Dystric) (Latossolos Vermelhos distróficos), and the Savanna (Cerrado) Biome is been degraded, near Vilhena county. Over the structural step in the border of "Planalto dos Parecis" and the Depression of Rio Guaporé, soils are mainly shallow as Leptosols, and in a minor quantity, Haplic Acrisols (Clayic). Over the mafics and flood basalts of "Planalto dos Parecis" in a region of a major conflict on the deforestation arch around Alta Floresta do Oeste, are developed high fertile soils, Haplic Lixisols (Chromic) and, in minor extent, Haplic Luvisols (Chromic), Chernozems, and eutric Cambisols).

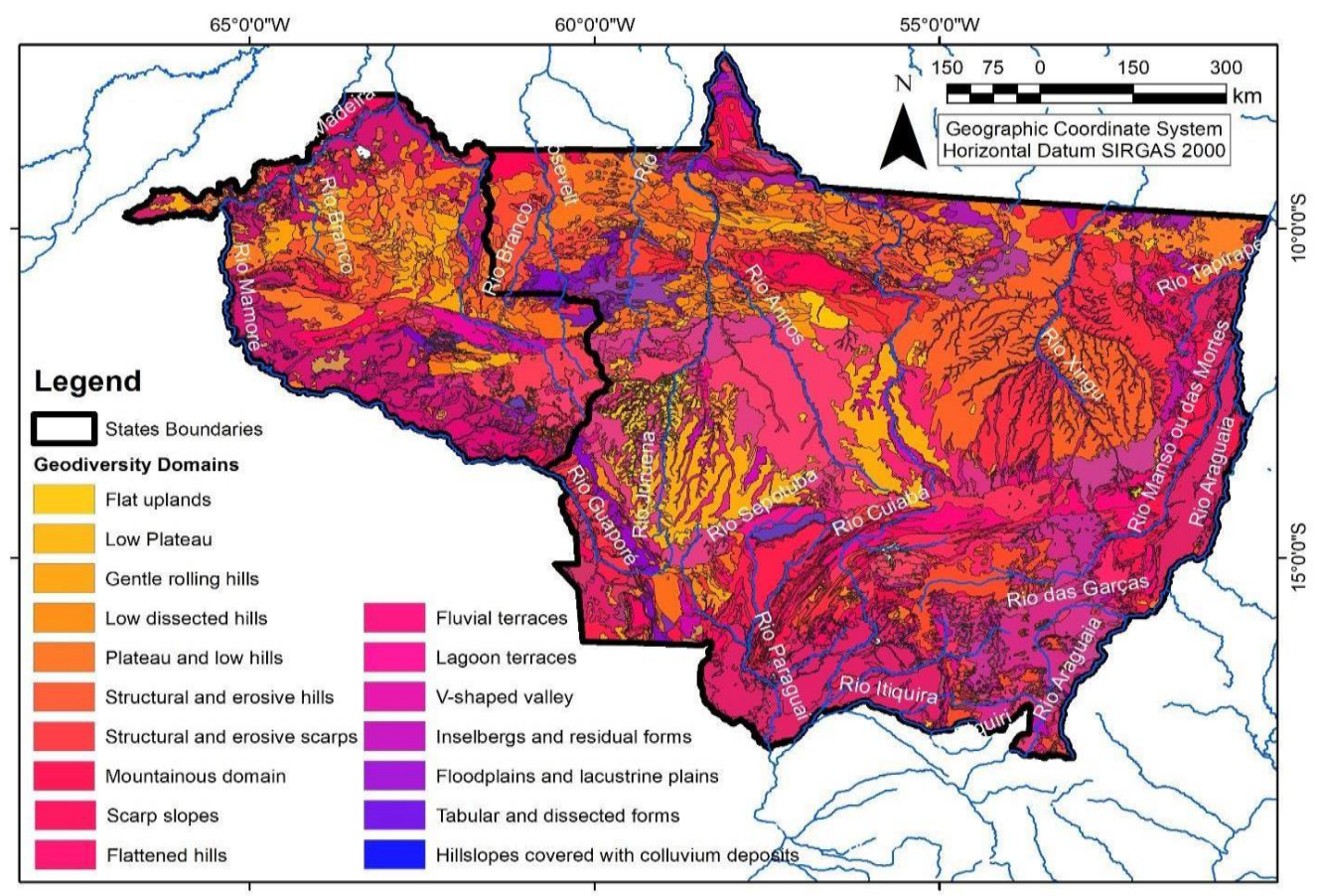

Figure 4. Location of studied area of SWAM, showing the Geodiversity Domains, based in CPRM (2006). 
Table 2. Characteristics of macro regions in the states of Mato Grosso and Rondônia, Southwestern Amazon Region, Brazil. Adapted from Mello (2007).

\begin{tabular}{|c|c|c|c|c|}
\hline Region & Topography & $\begin{array}{c}\text { Soil (WBR, } \\
\text { 2015) }\end{array}$ & $\begin{array}{l}\text { Climate and average } \\
\text { annual rainfall }(\mathrm{mm})\end{array}$ & Vegetation \\
\hline $\begin{array}{c}\text { Paraná } \\
\text { Basin }\end{array}$ & $\begin{array}{l}\text { Flat with large } \\
\text { plateaus }\end{array}$ & $\begin{array}{l}\text { Ferralsols; } \\
\text { Arenosols }\end{array}$ & $\begin{array}{c}\text { Am, Cwa }(1,250- \\
1,750)\end{array}$ & Savanna sensu stricto \\
\hline $\begin{array}{l}\text { Parecis } \\
\text { Plateau }\end{array}$ & $\begin{array}{l}\text { Flat with large } \\
\text { plateaus }\end{array}$ & $\begin{array}{l}\text { Arenosols; } \\
\text { Ferralsols }\end{array}$ & Ami $(1,500-2,250)$ & $\begin{array}{c}\text { Cerrado sensu stricto } \\
\text { and seasonal semi } \\
\text { deciduous forest }\end{array}$ \\
\hline $\begin{array}{c}\text { Araguaia } \\
\text { Depression }\end{array}$ & $\begin{array}{c}\text { Flat areas and rolling } \\
\text { hills frequently } \\
\text { waterlogged }\end{array}$ & Fluvisols & Ami $(1,250-2,000)$ & $\begin{array}{c}\text { Open Savanna } \\
\text { (dominated by grasses) } \\
\text { and Savanna s.s. }\end{array}$ \\
\hline $\begin{array}{c}\text { Cuiabá } \\
\text { Depression }\end{array}$ & $\begin{array}{l}\text { Flat areas and rolling } \\
\text { hills }\end{array}$ & $\begin{array}{c}\text { Cambisols, } \\
\text { Regosols }\end{array}$ & $\operatorname{Am}(1,500-1,750)$ & Savanna sensu stricto \\
\hline $\begin{array}{c}\text { Guaporé } \\
\text { Depression }\end{array}$ & Mostly flat & $\begin{array}{l}\text { Ferralsols, } \\
\text { Acrisols, } \\
\text { Regosols }\end{array}$ & $\begin{array}{c}\text { Ami }(1,750-2,250) \\
\text { Ami, } \\
\text { Am }(1,500- \\
1,750)\end{array}$ & $\begin{array}{l}\text { Open Amazon forest } \\
\text { (north) and seasonal } \\
\text { semi deciduous forest } \\
\text { to Savanna (south) }\end{array}$ \\
\hline $\begin{array}{l}\text { Northeastern } \\
\text { Mato Grosso }\end{array}$ & $\begin{array}{l}\text { Irregular with rolling } \\
\text { hills }\end{array}$ & Acrisols & Ami $(2,000-2,500)$ & $\begin{array}{l}\text { Cerrado to seasonal } \\
\text { semi deciduous forest }\end{array}$ \\
\hline $\begin{array}{c}\text { Northern } \\
\text { Mato Grosso }\end{array}$ & $\begin{array}{l}\text { Irregular with rolling } \\
\text { hill }\end{array}$ & $\begin{array}{l}\text { Acrisols, } \\
\text { Ferralsols, } \\
\text { Cambisols } \\
\end{array}$ & $\begin{array}{l}\text { Awi, Ami }(2,000- \\
2,750)\end{array}$ & $\begin{array}{c}\text { Open Amazon forest to } \\
\text { forest }\end{array}$ \\
\hline $\begin{array}{l}\text { Northern } \\
\text { Rondônia }\end{array}$ & Predominantly flat & Ferralsols & Awi $(2,000-2,500)$ & Open Amazon forest \\
\hline $\begin{array}{c}\text { Central } \\
\text { Rondônia }\end{array}$ & $\begin{array}{l}\text { Varies between flat } \\
\text { areas and rolling hills }\end{array}$ & $\begin{array}{l}\text { Acrisols, } \\
\text { Ferralsols }\end{array}$ & $\begin{array}{l}\text { Awi, Ami }(1,750- \\
2,250)\end{array}$ & Open Amazon forest \\
\hline Pantanal & $\begin{array}{l}\text { Mostly flat } \\
\text { frequently } \\
\text { waterlogged }\end{array}$ & $\begin{array}{l}\text { Arenosols, } \\
\text { Planosols }\end{array}$ & $\operatorname{Am}(1,500-1,750)$ & $\begin{array}{l}\text { Open Savanna and } \\
\text { seasonal semi } \\
\text { deciduous forest }\end{array}$ \\
\hline
\end{tabular}

As one example of devastation in the region, the largest open tin mine (cassiterite) in the world is situated in Ariquemes, Rondônia State, the "Garimpo Bom Futuro", in pegmatites associated with A-type granites (Bettencourt et al., 1999), with geochemical affinities with LCT- pegmatites (Lithium-CesiumTantalum, of Černý \& Ercit, 2005) hosted in acid granites and sub volcanics of the Younger Granites of Rondônia (Bettencourt et al., 1999; Bilal et al., 1993; Bilal et al., 1997). Groundwater is contaminated around this open mine by chemicals, which can be soluble toxic compounds including heavy metals (Vanuchi et al., 2014).

\subsection{Reference Values to SWAM Soils: a reflection over the limits applied.}

The QRVs established for Co in the states of Mato Grosso (MT) and Rondônia (RO) were higher than the QRVs established by national brazilian directives, regardless of the percentile used (CONAMA, 2009). For the USEPA 3051A extractant, the calculated QRV was close to the prevention value $\left(25 \mathrm{mg} \mathrm{\textrm {kg } ^ { - 1 }}\right.$ ) established by CONAMA (2009), as can be observed at the Figure 5 . The prevention value is the threshold concentration of a given substance in soils and represents an intermediate stage between the QRV and the research value. It is thus necessary to monitor Co levels in the soils of MT and RO. The QRVs obtained by Santos \& Alleoni (2013) for MT and RO are lower than those for SP, with the exception of Co and Cr. They are lower than those found by Paye et al., (2010) in soils of Espírito Santo State, Brazil, for $\mathrm{Cr}, \mathrm{Ni}$, and $\mathrm{Zn}$, but higher for $\mathrm{Co}, \mathrm{Cu}$, and $\mathrm{Pb}$. Differences in the QRVs reported in the Brazilian and international literature could be the effect of different parent materials and soil classes, and the fact that concentrations of HME depend on pedogenetic processes (Caires, 2009; Vázquez \& Anta 2009; Bini et al. 2011; Ramos-Miras et al. 2011). Under Brazilian conditions, the QRVs proposed by Fadigas et al. (2006) for values of the mean upper quartile were generally higher than the QRVs determined for soils of RO and MT, with the exception of Co $\left(8 \mathrm{mg} \mathrm{kg}^{-1}\right)$ and $\mathrm{Cu}\left(25 \mathrm{mg} \mathrm{kg}^{-1}\right)$ (Santos \& Alleoni, 2013). 


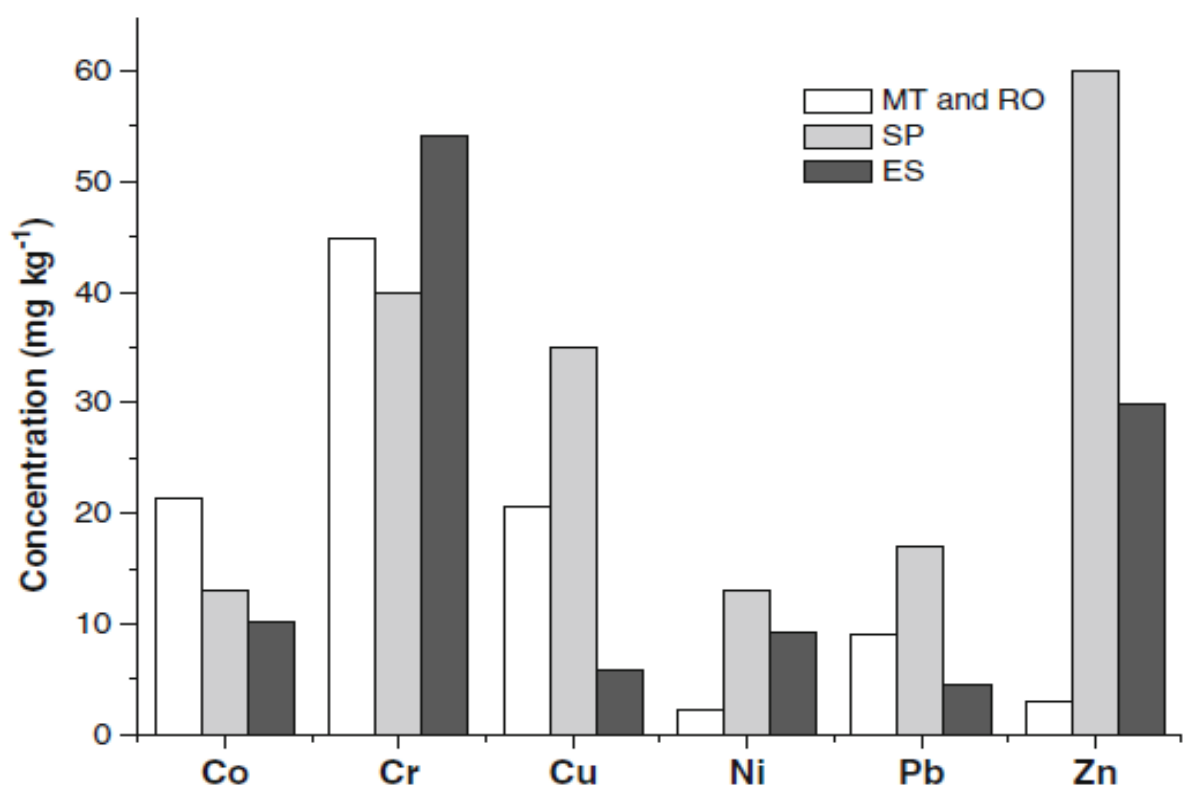

Figure 5. The QRVs for heavy metals obtained for soils from the states of RO, MT, ES and SP based on the 75th percentile. Adapted from Santos \& Alleoni, 2013.

The possibility of attain the maximum permissible concentration, not only for $\mathrm{Cd}$, but also for other elements evaluated, increases with larger quantities of phosphates fertilizers associated with sewage sludge and other fertilizers containing trace elements. Ramalho et al. (1999) availed the use of polluted water and phosphate fertilizers combined, and observed that soils that received 25 years of phosphate fertilizers showed a noticeable increase of $\mathrm{Cd}(0.66 \mathrm{mg}$ $\left.\mathrm{kg}^{-1}\right)$ when compared with control area $\left(0.5 \mathrm{mg} \mathrm{kg}{ }^{-1}\right.$ $\mathrm{Cd}$ ), without however elevate it to critical levels.

Independent determination for the different regions of Brazil is undoubtedly necessary to supply this key information. These values show quality assessments and are legally used to establish maximum permissible limits. Background levels of heavy metals in the soils of Mato Grosso and Rondônia (Santos \& Alleoni, 2013) had the following decreasing order: $\mathrm{Cr}>\mathrm{Zn}>\mathrm{Cu}>\mathrm{Co}>\mathrm{Pb}>\mathrm{Ni}>$ and $\mathrm{Cd}$ (AR, Acqua Regia method) and $\mathrm{Cr}>\mathrm{Co}>$ $\mathrm{Cu}>\mathrm{Pb}>\mathrm{Zn}>\mathrm{Ni}>\mathrm{Cd}$ (USEPA 3051 method), stressing the value of standardizing the methods of VRQs obtention.

The Table 3 presents the Quality Reference Values comparing the existing QRVs to Brazilian States, and to European countries.

Table 3. Reference values (QRVs) for HME in Brazilian States and other countries. (Adapted from Lima et al., 2016).

\begin{tabular}{|c|c|c|c|c|c|c|c|c|}
\hline \multirow{2}{*}{ Elements } & \multicolumn{3}{|c|}{ Brazilian Federations (States) Values (mg kg-1) } & \multicolumn{2}{c|}{ International Values (mg kg-1) } \\
\cline { 2 - 10 } & $\begin{array}{c}\text { Rio de } \\
\text { Janeiro }\end{array}$ & $\begin{array}{c}\text { São } \\
\text { Paulo }\end{array}$ & $\begin{array}{c}\text { Mato } \\
\text { Grosso e } \\
\text { Rondôni } \\
\mathbf{a}\end{array}$ & $\begin{array}{c}\text { Espírito } \\
\text { Santo }\end{array}$ & $\begin{array}{c}\text { Minas } \\
\text { Gerais }\end{array}$ & $\begin{array}{c}\text { Netherland } \\
\text { S }\end{array}$ & China & USA \\
\hline $\mathbf{C d}$ & $0.3-1.6$ & $<0.5$ & $<0.05$ & $<0.13$ & 0.55 & 0.8 & 0.07 & 1.6 \\
\hline $\mathbf{C u}$ & $2-119$ & 35 & 16.5 & 5.57 & 30.94 & 36 & 20 & 17 \\
\hline $\mathbf{N i}$ & $5-35$ & 13 & 1.3 & 6.65 & 30.17 & 35 & 23.4 & 13 \\
\hline $\mathbf{P b}$ & $3-40$ & 17 & 8.1 & 8.79 & 3.94 & 85 & 23.6 & 16 \\
\hline $\mathbf{Z n}$ & $6-79$ & 60 & 6.8 & 22.61 & 13.11 & 140 & 67.7 & 48 \\
\hline
\end{tabular}

To be compared worldwide all values presented in Table 3 are taken only from soils with $10 \%$ of organic matter and $25 \%$ of clay minerals. The restriction is due to strong correlation between HME, clay minerals and Soil Organic Matter (SOM) contents. Higher the SOM content leads to higher levels of HME. Sandy soils are poor in HME when compared with argillic and organic ones. The highest allowed levels in EU community are $3 \mathrm{mg} \mathrm{Cd} \mathrm{kg}{ }^{-1}$, $150 \mathrm{mg} \mathrm{Zn} \mathrm{kg}{ }^{-1} ; 140 \mathrm{mg} \mathrm{Cu} \mathrm{kg}{ }^{-1}$ and $50 \mathrm{mg} \mathrm{Pb} \mathrm{kg}{ }^{-1}$ (Chaudri et al., 1993). In Poland, those limits are, for arable soil $3 \mathrm{mg} \mathrm{Cd} \mathrm{kg}^{-1}, 300 \mathrm{mg} \mathrm{Zn} \mathrm{kg}{ }^{-1}$ and $200 \mathrm{mg}$ 
$\mathrm{Pb} \mathrm{kg}^{-1}$ (Chlopecka et al., 1996). According to EU recommendations, soil fertilised with sewage sludge should not contain more than $3 \mathrm{mg} \mathrm{kg}^{-1} \mathrm{Cd}$ (86/278/EC/12-6-1986). Soil Guideline Values (SGVs) for cadmium in the Netherlands are presented according to land use in Table 4.

The SGVs apply only to cadmium and its inorganic compounds. For residential $\left(10 \mathrm{mg} \mathrm{kg}^{-1} \mathrm{Cd}\right)$ allotment $\left(1.8 \mathrm{mg} \mathrm{kg}^{-1} \mathrm{Cd}\right)$ and commercial $(230 \mathrm{mg}$ $\mathrm{kg}^{-1} \mathrm{Cd}$ ) land uses, SGVs are based on estimates representative of lifetime exposure to soil contaminants, particularly, the renal toxicity of cadmium is based on considerations of the kidney burden accumulated over 50 years or so (Environment Agency, 2009d).

European Commission recently proposed a regulation (European Union Regulation-EC 2016) instructing stringent limits of cadmium in phosphate fertilizers commercialization, considered as major pollutants and therefore threatens population health. The measure adopted in this work is expressed in $\mathrm{mg}$ cadmium $/ \mathrm{kg} \mathrm{P}_{2} \mathrm{O}_{5}$ and this is the way the cadmium content in phosphate fertilizers is expressed.

Table 4 - Background values, Intervention Values and Maximum Values in soil in function of its destination, established by the legislation in Netherlands - Soil Remediation Circular 2009a and Soil Quality Regulation 2006 ${ }^{\mathrm{b}}$, in Ribeiro (2013).

\begin{tabular}{|c|c|c|c|c|c|c|}
\hline \multirow[b]{2}{*}{ Elements } & \multirow{2}{*}{$\begin{array}{c}\text { Background } \\
\text { values }^{\mathrm{a}} \\
(\mathrm{mg} / \mathrm{kg})\end{array}$} & \multirow[b]{2}{*}{$\begin{array}{l}\text { Sediment }^{\mathrm{a}} \\
(\mathrm{mg} / \mathrm{kg})\end{array}$} & \multicolumn{2}{|c|}{$\begin{array}{c}\text { Maximum } \\
\text { Values }(\mathrm{mg} / \mathrm{kg})\end{array}$} & \multirow{2}{*}{$\begin{array}{c}\text { Intervention } \\
\text { Value }^{\mathrm{a}} \\
(\mathrm{mg} / \mathrm{kg})\end{array}$} & \multirow{2}{*}{$\begin{array}{c}\text { Intervention } \\
\text { Value }^{\mathrm{b}} \\
(\mathrm{mg} / \mathrm{kg})\end{array}$} \\
\hline & & & $\begin{array}{c}\text { Residentials } \\
\text { oil quality } \\
\text { class }^{\mathrm{a}}\end{array}$ & $\begin{array}{l}\text { Industrial } \\
\text { soil quality } \\
\text { class }^{\mathrm{a}}\end{array}$ & & \\
\hline As & 20 & 29 & 27 & 76 & 76 & 76 \\
\hline $\mathrm{Cd}$ & 0.6 & 0.8 & 1.2 & 4.3 & 13 & 13 \\
\hline Cr total & 55 & 100 & 62 & 180 & 180 & - \\
\hline $\mathrm{Cu}$ & 40 & 36 & 54 & 190 & 190 & 190 \\
\hline Hg Total & 0.15 & 0.6 & 0.83 & 4.8 & 36 & - \\
\hline $\mathrm{Pb}$ & - & - & - & - & - & 4 \\
\hline $\mathrm{Ni}$ & 50 & 85 & 210 & 530 & 530 & 530 \\
\hline $\mathrm{Zn}$ & 140 & 140 & 200 & 720 & 720 & 720 \\
\hline
\end{tabular}

Besides the proposals of no action and general actions for market incentives, the european propositions are in summary as follows, (in $\mathrm{Cd} / \mathrm{kg}$ $\mathrm{P}_{2} \mathrm{O}_{5}$ ): (i) an initial limit of $60 \mathrm{mg}$ will apply as soon as the regulation comes into force: (ii) more stringent limit of $40 \mathrm{mg}$ will phase in three years later; (iii) the lowest limit of $20 \mathrm{mg}$ will come into force nine years after the regulation initiation and (iv) a new regulation setting a Community limit value for cadmium content in phosphate fertilizers at $60 \mathrm{mg}$ decreasing over time to 40 and eventually $20 \mathrm{mg}$ if decadmiation becomes available on industrial scale. Flexibility should be given to allow Member States to set limit values at either 40 or $20 \mathrm{mg}_{5}$ in the light of specific conditions in their territories (Ulrich, 2019). Fertilizers would be labelled to provide an indication, which limit value for cadmium they comply with the proposition in European Union Regulation EC (2016) finally stated that $60 \mathrm{mg}$ is to entry in force and apply since 1 January 2018. Reducing targets are, for 3 years, $40 \mathrm{mg}$ and for 20 years, $20 \mathrm{mg}$. The considered target value $20 \mathrm{mg}$ is an effort and desirable, but this change could also be a negative impact on populations and economies in underdeveloped countries, particularly in North Africa, if costs in innovation on decadmiation process increase (Ulrich, 2019).

\section{CONCLUSIONS}

Past climates and the prevailing particular tropical environmental conditions in Brazil promote intense weathering of some rocks, with a change in mineralogy, forming argillic and Governmental environmental agencies prefer the stringent 75th percentile. Fertilizers stakeholders are against this choice arguing that since the data used to obtain those values come from areas that have hardly been impacted, and from soils that are broadly representative of a region, data considered to be anomalous could represent natural soil variability (European Union Regulation EC, 2016). Studies from Santos \& Alleoni (2013) on methods for extracting heavy metals in soils from the SWAM describes levels of $\mathrm{Cd}$ in all the samples were below the detection limit, and limit of quantification was established as QRV, excluded from other procedures for statistical interpretation, as suggested by the CONAMA (2009).

The metallic elements traces $(\mathrm{Cd}, \mathrm{Cr}, \mathrm{Cu}, \mathrm{Hg}$, $\mathrm{Ni}, \mathrm{Pb}, \mathrm{Zn}$ ) are rapidly increasing in soils with the indiscriminate use of fertilizers, animal manures and urban sewage sludge. As some of them are potentially 
toxic and present no agronomic interest, their presences generate a major concern. The agricultural use of the residual mud allows the recycling of precious components such as the organic matter and many nourishing elements of the plant (Logan \& Harrison, 1995). Residual muds can replace or reduce the use of these imported and expensive fertilizers. Economic and environmental issues are in the center of this debate, and this paper intends to expose the main advances in the knowledge.

Limits of cadmium on fertilizers in Brazil should be higher to meet health and environmental global protection goals. States in Brazil that have previously established base levels need to review recent research on the health effects of cadmium, the increment of cadmium in soils, and the contribution of fertilizer to cadmium input in surface waters. Tapajós, Xingu and Madeira hydrographic basins act as sinks to surface flows carrying HME, notably in the Arinos, Rio Verde, Teles Pires, Juruena, Rio Branco, Guaporé and Marmoré rivers, situated at the main affected areas of soybean croplands expansion in SWAM. The north-south arrow of BR-163 national route is the main pressure area to the deforestation arch, threaten forests, savannas, preservation areas and indigenous reserves with the possibility of $\mathrm{HME}$ contamination in a short-time period if the regulation to restrict the use of rich $\mathrm{Cd}$ phosphate fertilizers is not well established.

Soil contamination by HME became a punctual problem in Amazon, due the illegal mining activities, but in extensive way in the croplands, settled over plantations with the continuous use of phosphatebased fertilizers that are rich in HME. The hope to soils protection resides on the effectiveness of restrictive legislation, and at the principle of the legislation to establish, in a clear way, the rules, regulations, and norms. This is the base to control the degradation by respecting the environmental aspects and potentials of these activities and highlighting the importance of monitoring of those elements.

\section{Acnowledgements}

The authors wish to thank University Federal Rurale of Rio de Janeiro, CNPq, CNRS and Ecole des Mines de Saint Etienne respectively for their valuable help and support.

\section{REFERENCES}

Abdel-Haleem, A.S., Scroon, A., El-Bahi, S.M. \& Zohny, E. 2001. Heavy metals and rare earth elements in phosphate fertilizer components using instrumental neutron activation analysis. Applied Radiation and Isotopes, v.55, p.569-573.
Abollino, O.; Aceto, M.; Malandrino, M.; Mentasti, E.; Sarzanini, C.; Petrella, F. 2002. Heavy metals in agricultural soils from Piedmont, Italy. Chemosphere, 49: 545-557.

Alloway, B.J. 1995. Cadmium In Heavy Metals In Soils (2nd Edn.). (Ed. B.J. Alloway). London: Blackie Academic \& Professional. 368p.

Alloway, B.J., 2010. Heavy Metals In Soils - Trace Metals And Metalloids In Soils And Their Bioavailability. New York: Springer. Pp. 11-493.

Amaral Sobrinho, N.M.B.; Costa, L.M.; Oliveira, C.; Velloso, A.C.X. 1992. Metais pesados em alguns fertilizantes e corretivos. Revista Brasileira de Ciência do Solo, v.16, p.271- 276.

Amaral Sobrinho, N.M.B. 1993. Interação dos metais pesados de resíduos siderúrgicos com um podzólico Vermelho Amarelo. Viçosa UFV. Dsc.Thesis $.163 \mathrm{p}$

Bak, J.; Jensen, J.; Larsen, M. M.; Pritzl, G.; ScottFordsmand, A. 1997. Heavy metal monitoringprogramme in Denmark. Science of the Total Environment, 207: 179-186.

Bernoux, M.; Graça, P.M. A.; Fearnside, P. M.; Cerri, C. C.; Feigl, B. \& Piccolo, M. C. 2001. Carbon storage in biomass and soils. In M. E. McClain (Ed.), The biogeochemistry of the Amazon Basin and its role in a changing world. Oxford University Press. p. 165- 184.

Bettencourt, J.S.; Tosdal, R.M.; Leite Júnior, W.B. \& Payolla, B.L. 1999. Mesoproterozoic rapakivi granites of the Rondônia tin province and adjacent area, southwestern border of the Amazonian Craton, Brazil: I. Reconnaissance U-Pb geochronology and regional implications. Precambrian Research, 95: 45-67.

Bilal, E.; Moutte, J.; Botelho, N.; Marini, O.; Andrade, G. 1997. Geochemistry of two proterozoic A-type granites of Goias state, Brazil: possible links with rapakivi series. Annals of the Brazilian Academy of Science. 69 (3): 349-365.

Bilal, E.; Moutte, J.; Botelho, N.; Andrade, G. 1993. The tin bearing endoskarns veins of Mata Azul (Goias, Brasil). In Current research in geology applied to ore deposits. Edited by P. Fenoll Hach-Ali, Torres Ruiz and Gervilla, A.A. Balkema/ Rotterdam/ Brookfield, pp 711-714.

Bini, C.; Sartori, G.; Wahsha, M.; Fontana, S. 2011. Background levels of trace elements and soil geochemistry at regional level in NE Italy. Journal of Geochemical Exploration, 109: 125-133.

Bizarro, V.G.; Meurer, E.J.; Tatsch, F.R.P. 2008. Teor de cádmio em fertilizantes fosfatados comercializados no Brasil. Ciência Rural, 38:247250.

Brus, D. J., Lame, F. P. J. \& Nieuwenhuis, R. H. 2009. National baseline survey of soil quality in the Netherlands. Environmental Pollution, 157: 20432052.

Caires, S. M. 2009. Determination of natural heavy metals levels in soils of Minas Gerais State to help 
definition of background levels. Thesis, Universidade Federal de Viçosa, Viçosa, 64 p.

Campos, M.L.; Pierangeli, M.A.P.; Guilherme, L.R.G.;Marques, J.J.; Curi, N. 2003. Baseline concentration of heavy metals in Brazilian Latosols. Communications in Soil Science and Plant Analysis, v.34, p.547-558.

Campos, M.L.; Silva, F.N.; Furtini Neto, A.E.; Guilherme, L.R.G.; Marques, J.J.; Antunes, A.S. 2005. Determinação de cádmio, cobre, cromo, níquel, chumbo e zinco em fosfato de rocha. Pesq. Agropec. Bras., 40:361-367, 2005.

Casarini, D. C. P. (2000) Proposta de valores de referência de qualidade e intervenção para solos e águas subterrâneas no estado de São Paulo. In: Sem. Internacional sobre Qualidade de Solos e Águas Subterrâneas, 2., SP. An. CETESB, 165p.

Černý, P.; Ercit, T.S., 2005. The classification of granitic pegmatites revisited. Can. Mineral. 43, 2005-2026.

Chaudri, A.M.; Mcgrath, S.P.; Giller, K.E.; Rietz, E. \& Sauerbeck, D.R.1993. Enumeration of indigenous Rhizobium leguminosarum biovar trifolii in soil previously treated with metal-contaminated sewage sludge. Soil Biol. Biochem., 25:301-309.

Chen, J., Wei, F., Zheng, C., Wu, Y., \& Adrian, D. C. 1991. Background concentrations of elements in soils of China. Water Air Soil Pollution, p. 57-58, 699-712.

Chen, J. S., Deng, B. S., Pan, M., Wang, X. J., Zeng, S. Q., \& He, Q. 1993. Geographical tendencies of trace element contents in soils derived from granite, basalt and limestone of eastern China. Pedosphere, 3: $45-55$.

Chen, T. B., Wong, J. W. C., Zhou, H. Y., \& Wong, M. H. 1997. Assessment of trace metal distribution and contamination in surface soils of Hong Kong. Environmental Pollution, 96: 61-68.

Chen, M., Ma, L. Q., \& Harris, W. G. 1999. Baseline concentrations of 15 trace elements in Florida surface soils. Journal of Environmental Quality, 28: 1173- 1181 .

Chlopecka, A.; Bacon, J.R.; Wilson, M.J. and KAY, J.1996. Forms of Cadmium, Lead, and Zinc in contaminated Soils from Southwest Poland. Journal of Environmental Quality, 25:69-79.

Coelho, M.R.; Santos, H.G.; Silva, E.F. \& Aglio, M.L.D.O. 2002. Recurso natural solo. In: Manzatto, C.V.; Freitas Jr., E. \& Peres, J.R.R. Uso agrícola dos solos brasileiros. Rio de Janeiro, Embrapa Solos, p.1-11.

Companhia Nacional de Abastecimento - CONAB. 2015. Séries históricas de produção de grãos. Brasília: 2015. Disponível em: <http://www.conab.gov.br>.

Companhia de Tecnologia De Saneamento Ambiental CETESB. 2016 . Valores Orientadores para Solos e Águas Subterrâneas no Estado de São Paulo 2016. Publicado no Diário Oficial Estado de São Paulo - Caderno Executivo I (Poder Executivo, Seção I), edição $n^{\circ} 126$ (219) do dia 24/11/2016
Pp.55- 56.

Conselho Nacional De Meio Ambiente - CONAMA. 2009. Resolução no 420, de 28 de dez. de 2009. Dispõe sobre critérios e valores de qualidade do solo quanto à presença de substâncias químicas e estabelece diretrizes para o gerenciamento ambiental de áreas contaminadas por essas substâncias em decorrência de atividades antrópicas. Diário Oficial da União, no 249 , de 30 de dez. de 2009. p.81.

CPRM Serviço Geologico do Brasil 2006. Texto explicativo dos mapas geológico e de recursos minerais do estado do amazonas, escala 1:1.000.000. Manaus, pp. 153.

Echevarria, G. And Morel. J-1. 2006. Caractérisation de la biodisponibilité des éléments en traces dans les sols et validation de mesures fiables. Sols et environnement. Vandœuvre-lès-Nancy.,57p

Environment Agency, 2009a. Using Soil Guideline Values. Science Report Sc050021/Sgv Introduction. Bristol: Environment Agency.

Environment Agency, 2009b. Updated Technical Background To The Clea Model. Science Report Sc050021/Sr3. Bristol: Environment Agency.

Environment Agency, 2009c. Human Health Toxicological Assessment of Contaminants in Soil. Science Report Sc050021/Sr2. Bristol: Environment Agency.

Environment Agency, 2009d. Contaminants in Soil: Updated Collection of Toxicological Data and Intake Values For Humans; Cadmium. Science Report Sc050021/Sr Tox7. Bristol: Environment Agency.11p.

Environment Agency, 2009e. Supplementary information for the derivation of SGV for cadmium and its compounds. Science Report/ Technical Review Cadmium. Bristol: Environment Agency.

Empresa Brasileira de Pesquisa Agropecuária EMBRAPA. 1999. Manual de métodos de análise de solo. Centro Nacional De Pesquisa De Solos. 2.ed. Rio de Janeiro, 212p. (Embrapa-CNPS. Documentos, 1)

ESRI database. 2018. ArcGIS Desktop version 10.3. Environmental Systems Research Institute, Redlands, California.

European Union Regulation EC (2016) Limits for cadmium in phosphate fertilisers. Proposal for a Regulation of the European Parliament and of the Council amending Regulations (EC) No 1069/2009 and (EC) No 1107/2009. 91p.

Fadigas, F. S.; Amaral Sobrinho, N. M. B.; Mazur, N.; Anjos, L. H. C.; Freixo, A. A. (2006) Proposição de valores de referência para a concentração natural de de metais pesados em de solos brasileiros. Revista Bras. de Eng. Agrícola e Ambiental v.10, n.3. p.699-705.

Fearnside, P.M. 2001. Soybean cultivation as a threat to the environment in Brazil. Environ Conserv 28: 23 38.

Ferguson, J. E., 1990, The Heavy Elements, In: 
Chemistry, Environmental Impact and Health Effects, Oxford, Pergamon Press., 211-212.

Fonseca, M.G.; Alves, L.M.; Aguiar, A.P.D.; Arai, E.; Anderson, L.O.; Rosan, T.M.; Shymabukuru, Y.E.; Aragão, L.E.O.C. 2019 Effects of climate and land-use change scenarios on fire probability during the 21st century in the Brazilian Amazon. Glob Change Biol.;00:1-16.

Gabe, U; Rodella, A.A., (1999). Trace Elements in Brazilian Agricultural Limestones and Mineral Fertilizers. Communication Soil Science Plant Anal. 30(5/6):605-620.

Gray, M.; Gordon, J.E.; Brown, E. 2013. Geodiversity and the ecosystem approach: the contribution of geoscience in delivering integrated environmental management. Proceedings of the Geologists' Association Vol 124, Issue 4. Pp 659-673.

Gusso, A; Ducati, J.R.; Bortolotto, V.C. 2017. Analysis of soybean cropland expansion in the southern Brazilian Amazon and its relation to economic drivers. Acta Amaz. vol.47 no.4 Manaus.Pp281-292

Holmgren, G. S.; Meyer, M.W. Chaney, R. L.; Daniels, R. B. 1993. Cadmium, lead, zinc, cooper, and nickel in agricultural soils of the United States of America. Journal of Environmental Quality, 22: 335-348.

Horckmans, L; Swennen, R., Deckers, J; Maquil, R. 2005. Local background concentrations of trace elements in soils: a case study in the Grand Duchy of Luxembourg. Catena, 59: 279-304.

Instituto Brasileiro de Geografia e Estatística - IBGE. Levantamento sistemático da produção agrícola, setembro 2014. Rio de Janeiro: IBGE. Disponível em: <http://www.ibge.gov.br>. Access: 10 nov. 2014

International Organisation For Standardisation-ISO. 2005. Soil quality: guidance on the determination of background values. ISO 19258.

Jarup, L.; Akesson, A. 2009. A current status of cadmium as an environmental health problem. In: Toxicology and Applied Pharmacology 238(3):201-8

Kabata-Pendias, A.; Pendias, H. 2001. Trace Elements in Soils and Plants, Third Edition. Boca Raton: CRC Press LLC.

Langenbach, T.; Sarpa, M. .1985. Teor de cádmio nos fertilizantes fosfatados brasileiros. Revista Brasileira de Ciência do Solo, v.9, p.179-181,

Latrubesse, E. M., Bocquentin, J., Santos, C. R., \& Ramonell, C. G. 1997. Paleoenvironmental model for the late cenozoic of southwestern Amazonia: paleontology and geology. Acta Amazonica., 27, 103-118.

Lima, H. N., Mello, J. W. V., Schaefer, C. E. G. R., Ker, J. C., \& Lima, A. M. N. 2006. Mineralogia e química de três solos de uma topossequiência da bacia sedimentar do alto Solimões, Amazônia Ocidental. Revista Brasileira de Ciência do Solo., 30, 59-68.

Lima, E.S.A.; Amaral Sobrinho, N. M. B., Vidal, D.; Coutinho, I.B. 2016. Comparing Methods for Extracting Heavy Metals from Histosols for
Establishing Quality Reference Values. Revista Brasileira de Ciência do Solo., 40.14p

Logan, T.J., Harrison, B.J. 1995. Physical characteristics of alkaline stabilized sewage sludge (Nitro soil. and their effects on soil properties. J. Environ. Quality. 24, pp. 153-164.

Lopes, A.S. 2003. Reservas de fosfatados e produção de fertilizantes fosfatados no Brasil e no mundo [Phosphate reserves and phosphate fertiliser production in Brazil and the world] . In: Simpósio sobre fósforo na agricultura brasileira, 2003, Piracicaba. Anais. Piracicaba: Potafos/Anda,. 1 CD-ROM.

Martinez-Lladó, X., Vilà, M., Martí, V., Rovira, M., Domènech, J. A., \& Pablo, J. 2008. Trace element distribution in topsoils in Catalonia: background and reference values and relationship with regional geology. Environmental Engineering Science, 25: 863-878.

McGrath, S. P., \& Zhao, F. J. 2006. Ambient background metal concentrations for soils in England and Wales. London: Environment Agency.

Mello, F. F. C. 2007. Estimates of soil carbon stocks for Rondônia and Mato Grosso states previously to anthropic intervention. Thesis, University of Sao Paulo (ESALQ/USP), pp. 89.

Mello, F.M; Bilal, E.; Mesquita, G.N.C.; Teodoro, M.E.L.R., Araujo, T.P.; Gallice, F. 2018. Background and reference values for the cadmium contents of Brazilian soils compared. Rom. J.Mineral Deposits, v.91, No. 1-2, p. 91-96.

Melo, L.C.A.; Silva, C.A. 2008. Influência de métodos de digestão e massa de amostra na recuperação de nutrientes em resíduos orgânicos. Química Nova. 2008;31:556-61.

Morton, D C; De Fries, RS; Shimabukuro, Y. E.; Anderson, L.O.; Arai, E.; del Bom EspiritoSanto, F.; Freitas, R.; Morisette, J. 2006. Cropland expansion changes deforestation dynamics in the southern Brazilian Amazon. Proc. Natl. Acad. Sci. 103:14637-14641.

Neill, C.; Coe, Mt., Shelby H. Riskin, H.S., Krusche, A.,Elsenbeer, H, Macedo, M.N, Mchorney,R., Lefebvre, P. Davidson E.A.; Scheffler, R.; Figueira, A.m.S. Porder, M.. Deegan, L.A. 2013. Watershed responses to Amazon soya bean cropland expansion and intensification. Phil Trans $R$ Soc B 368: 20120425.

Nobre, A.D.; Cuartas, L.A.; Hodnett, M.; Rennó, C.; Rodrigues, G.O.; Silveira, A.; Waterloo. M., Saleska, S. 2011. Height above the nearest drainage-a hydrologically relevant new terrain model. Journal of Hydrology 404.

Paye Sa, Henrique de; Mello, Jaime Wilson Vargas de; Abrahão, Walter Antônio Pereira; Fernandes Filho, Elpídio Inácio; Dias, Lívia Cristina Pinto; Castro, Maria Luisa Oliveira; Melo, Stefeson Bezerra de; França, Michele Milanez. 2010. Valores de referência de qualidade para metais pesados em solos no estado do espírito santo. 
Revista Brasileira de Ciência do Solo, 34, 6, 2041 2051

Pérez D.V., Santos F.A.; Santos F.T; Escaleira V., Bianchi S.; Pereira N.R. 2013. Comparação de métodos de digestão para determinação de metais em amostras de solos provenientes do estado do Mato Grosso do Sul. In: $17^{\circ}$ Encontro Nacional de Química Analítica. BH-MG, Soc. Bras.Quím.

Raij, B. van. 2003. Fósforo no solo e interação com outros elementos. In: simp. sobre fósforo na agricultura brasileira. Piracicaba. Anais. Piracicaba: Potafos/Anda. 1 CD-ROM.

Ramalho, J.F.G.P.; Amaral SobrinhO, N.M.B.; Velloso, A.C.X. 1999. Acúmulo de metais pesados em solos cultivados com cana-de-açúcar pelo uso contínuo de adubação fosfatada e água de irrigação. Revista Brasileira de Ciência do Solo, v.23, p.971979.

Ramos-Miras, J. J., Roca-Perez, L., Guzmán-Palomino, M.,Boluda, R., \& Gil, C. (2011). Background levels and baseline values of available heavy metals in Mediterranean greenhouse soils (Spain). Journal of Geochemical Exploration., 110, 186-192.

Ribeiro, M. A. C. 2013. Contaminação do solo por metais pesados [Soil contamination by heavy metals]. Lisbon. Universidade Lusófona de Humanidades e Tecnologias. Unpublished M.sc Dissertation. 249p.

Saldanha, M.F.C.; Pérez, D.V.; Meneguelli, N.A.; Moreira, J.C.; Vaitsman D.S. 1997. Avaliação de cinco tipos de abertura para determinação dos teores de ferro, manganês e zinco em alguns solos brasileiros.(Embrapa-CNPS,1).

Salonen, V.; Korkka-Niemi, K. 2007. Influence of parent Sediments on the concentration of Heavy Metals in Urban and Suburban soils in Turju, Finland. In: Applied Geomistry 22(5):906-918 M.

Sanchez, P. A.; Bandy, D.E. Villachica,J.H.; Nicholaides, J.J.; Sparks D.L (1982) Amazon Basin Soils: Management for Continuous Crop Production. Science, vol. 216, 21 may.

Santos S.N., Alleoni L.R.F. 2013. Methods for extracting heavy metals in soils from the southwestern Amazon, Brazil. Water Air Soil Pollut, 224:143046. doi:10.1007/s11270-012-1430-Z

Su, Y.Z.; Yang, R. 2008. Background concentrations of elements in surface soils and their changes as affected by agriculture use in the desert-oasis ecotone in the middle of Heihe River Basin, northwest China. Journal of Geochemical Exploration, 98: 57-64.

Ulrich, A.E., 2019. Cadmium governance in Europe's phosphate fertilizers: Not so fast? Sci. Total Environ. $\quad 650 \quad 541-545$. https://doi.org/10.1016/j.scitotenv.2018.09.014.

Usepa 1998a. Method 3050B Available in: http:// www.epa.gov/SW-846/pdfs/3050b.pdf. Access: feb. 2004.

Usepa. 1998b. Method 3051A. Available in: http://www.epa.gov/SW-846/3051a.pdf. Access in: mar. 2004

Vanuchi, V.CF.; Serpa, A.S.H.; Santos, R.R.; Baptista, R.A., Zan, A.R..2014. Análise Físico-químicas De Águas Oriundas Das Principais Lagoas E Poços Do Garimpo Bom Futuro - Ariquemes/RO. South American Journal of Basic Education, Technical And Technological, v. 1, p. 19-28

Vázquez, F. M.; Anta, R. C. 2009. Generic levels of heavy metals and other trace elements in soils em Galicia. Ed:Xunta de Galicia. 